\title{
Screening of HIV sero positive women for cervical abnormalities
}

\section{Meenakshi B. Chauhan, Sushila Chaudhary*, Sunita Singh, Manasi Juneja, Smiti Nanda}

Department of Obstetrics and Gynecology, Post Graduate Institute of Medical Sciences, Rohtak, Haryana, India

Received: 27 May 2018

Accepted: 26 June 2018

\section{*Correspondence:}

Dr. Sushila Chaudhary,

E-mail: sushilachaudhary68@gmail.com

Copyright: (c) the author(s), publisher and licensee Medip Academy. This is an open-access article distributed under the terms of the Creative Commons Attribution Non-Commercial License, which permits unrestricted non-commercial use, distribution, and reproduction in any medium, provided the original work is properly cited.

\section{ABSTRACT}

Background: Cancer cervix is a leading cause of death among women worldwide. Detection of cervical cancer in precancerous stage is $100 \%$ curable. Screening with Pap smear has reduced mortality by cervical cancer in developed countries many folds. The objective of the study is to determine prevalence of Cervical Intraepithelial Neoplasia (CIN) in HIV infected women and observe for associated lower genital infections and their correlation with CD4 counts.

Methods: The present study is a cross-sectional observational study conducted at PGIMS, Rohtak, Haryana for a period of 18 months. $150 \mathrm{HIV}$ patients and 150 age related control cases were taken. Pap smears were taken and analyzed for cervical abnormalities and genital infections.

Results: Of the 300 Pap smear $22(7.3 \%)$ has squamous intraepithelial abnormalities and $278(92.7 \%)$ negative for intra epithelial abnormalities. Prevalence of cervical intraepithelial abnormities among HIV positive $12 \%$ while among HIV negative it is $2.7 \%$. Cervical intraepithelial abnormalities were found in $40 \%$ and $3.5 \%$ of patients with CD4 count $<200$ and $>200$ respectively.

Conclusions: HIV increases the risk of cervical abnormalities. Frequent screening of these patients for cervical cancer is needed.

Keywords: HIV, Pap smears screening, Squamous intraepithelial lesion

\section{INTRODUCTION}

Cervical cancer is a leading cause of death among women worldwide. Cervical screening has reduced the incidence of cancer cervix in many advance countries. ${ }^{1,2}$ It has got a long pre-invasive state which could be detected and treated. So, screening is highly effective.

Cervical Intraepithelial Neoplasia (CIN) arises in an area of metaplasia in the transformation zone at the advancing squamo-columnar junction in most cases. CIN is most likely seen at menarche and after pregnancy when metaplasia is most active. Detection of cervical cancer in precancerous stage is $100 \%$ curable. Screening with Pap smear has reduced mortality by cervical cancer in developed countries many-folds. Association of cervical intraepithelial neoplasia and HPV infection approaches $90 \% .^{3}$ Incidence, prevalence and persistence of HPV with high risk subtype are more common with HIV infection and worsen with immuno-suppression like increased CD4 cell count and increased viral load. ${ }^{4}$ India faces large burden of HIV/AIDS (third highest number in world).

Authors have evaluated the HIV positive patients, attending Out Patient Department of Obstetrics and Gynecology at Pt. B.D. Sharma Post Graduate Institute of Medical Sciences, Rohtak, Haryana to establish the relationship between cervico-vaginal cytological abnormalities, state of HIV infection and CD4 count.

The objective of the study is to determine prevalence of Cervical Intraepithelial Neoplasia (CIN) in HIV infected 
women and observe for associated lower genital infections and their correlation with CD4 counts.

\section{METHODS}

The present study was conducted in the out-patient Department of Obstetrics and Gynecology and pathology of Pt. B.D. Sharma Post Graduate Institute of Medical Sciences, Rohtak, Haryana. A total of 150 HIV positive patients and 150 age matched control cases were taken.

\section{Inclusion criteria}

- $\quad$ Both HIV seropositive type 1 and 2 women attending ART clinic with age group18-45 years

- Patients sero-positivity tested by ELISA test and confirm by western blot test.

\section{Exclusion criteria}

- Pregnant women

- All diagnosed cervical cancer whether invasive or pre-invasive.

After an informed consent all women were interviewed regarding their social, obstetric, sexual, medical and treatment history. General physical, pelvic examination and cervico-vaginal, Pap smear of all enrolled women were done. Universal precautions were taken while collecting samples. Blood samples were taken to determine CD4 count. Cytological changes and genital infections were observed and compared between seropositive and sero-negative cases.

\section{Statistical analysis}

Statistical analysis was performed using IBM SPSS statistics (SPSS/IBM chicagoIL). The results were interpreted using Chi-square method.

\section{RESULTS}

The present study is a cross-sectional observational study conducted for a period of 18 months. Results are tabulated from 1-6.

A total of $150 \mathrm{HIV}$ positive and 150 control cases were taken.

Table 1 shows demographic profile of patients. All the women in present study were in reproductive age group of 19-45 years. Majority of women in present study were in the age group of 21-30 years followed by 31-40 years. Both the groups had comparable data in terms of age (independent samples t-test $\mathrm{p}>0.05$ ). Majority of women in both groups were multiparous and were comparable.

Nearly $51 \%$ women had their first intercourse before the age of 18 while $49 \%$ had after it. Only $2.6 \%$ (8/300) had sex before the age of 15 . Each one of them had sex with single partner only (Table 2).

Table 1: Demographic profile of patients.

\begin{tabular}{|llll|}
\hline $\begin{array}{l}\text { Age in } \\
\text { years }\end{array}$ & HIV-negative & HIV-positive & Total \\
\hline$<20$ & $2(1.3 \%)$ & $3(2 \%)$ & 5 \\
\hline $21-30$ & $76(50.6 \%)$ & $73(48.6 \%)$ & 149 \\
\hline $31-40$ & $59(39.9 \%)$ & $65(43.3 \%)$ & 124 \\
\hline$>40$ & $13(8.7 \%)$ & $9(6 \%)$ & 22 \\
\hline Mean+SD & $31.7 \pm 6.8$ & $31.2 \pm 6.1$ & \\
\hline p-value* & 0.47 & & \\
\hline Parity & & & 7 \\
\hline 0 & 1 & 6 & 249 \\
\hline $1-3$ & 126 & 123 & 44 \\
\hline$>3$ & 23 & 21 & 300 \\
\hline Total & 150 & 150 & \\
\hline *independent samples test & & \\
\hline
\end{tabular}

$43 \%$ HIV positive women had their CD4 counts $>350$ cells/ $\mu$ l while $23 \%$ were severely immune-compromised with CD4 count of $<200$ cells/ $\mu 1.33 \%$ had CD4 counts between 200-350/1 (Table 3).

Table 2: Distribution according to age at first intercourse.

\begin{tabular}{|llll|}
\hline $\begin{array}{l}\text { Age } \\
\text { (years) }\end{array}$ & HIV-negative & HIV-positive & Total \\
\hline$<18$ & $70(46.7 \%)$ & $84(56.0 \%)$ & $154(51.3 \%)$ \\
\hline$>18$ & $80(53.3 \%)$ & $66(44 \%)$ & $146(48.7 \%)$ \\
\hline Total & 150 & 150 & 300 \\
\hline
\end{tabular}

Table 3: Distribution of HIV positive women according to CD4 counts.

\begin{tabular}{|lll|}
\hline CD4 counts (cell/pl) & No. of patients & Percentage \\
\hline$<200$ & 35 & 23.3 \\
\hline $200-350$ & 50 & 33.3 \\
\hline$>350$ & 65 & 43.3 \\
\hline Total & 150 & 100 \\
\hline
\end{tabular}

Table 4: Distribution of epithelial abnormalities according to HIV status.

\begin{tabular}{|llll|}
\hline $\begin{array}{l}\text { Epithelial } \\
\text { abnormalities }\end{array}$ & $\begin{array}{l}\text { HIV } \\
\text { positive }\end{array}$ & $\begin{array}{l}\text { HIV } \\
\text { negative }\end{array}$ & Total \\
\hline ATYPIA+ & $18(12 \%)$ & $4(2.7 \%)$ & $22(7.3 \%)$ \\
\hline ATYPIA- & $132(88 \%)$ & $146(97.3 \%$ & $278(92.7 \%)$ \\
\hline Total & 150 & 150 & 300 \\
\hline
\end{tabular}

OR 18.5*,95 CI (5.5-61.7) $\mathrm{p}=0.002 ;{ }^{*}$ Chi-square test

Of the 300-pap smear, $278(92.7 \%)$ reported negative for intra-epithelial lesion and $22(7.3 \%)$ had squamous cell abnormalities. The prevalence of squamous cell abnormalities among HIV +ve was $12 \%$ (18/150) while among HIV -ve women it was $2.7 \%$ (4/150) a statistically 
significant difference (OR 18.5, 95\%CI (5.5-61.7) $\mathrm{p}=0.002$ ) (Table 4).

Cervical epithelial abnormalities were found in $40 \%$ and $3.5 \%$ of patients with CD4 count $<200$ and $>200$ respectively (OR 18.5, 95\% CI $(5.5-61.7) \mathrm{P}<0.00)$. Thus, in present study incidence of cervical atypia increased with falling CD4 counts (Table 5).

Table 5: Frequency distribution of epithelial cell abnormalities according to CD4 counts in HIV patients.

\begin{tabular}{|lll|} 
CD4 counts & ATYPIA+ & ATYPIA- \\
\hline $200(n=35)$ & $14(40 \%)$ & $21(60 \%)$ \\
\hline$>200(n=115)$ & $4(3.5 \%)$ & $111(96.5 \%)$ \\
Total & 18 & 132 \\
\hline
\end{tabular}

OR 18.5*,95 CI (5.5-61.7) p<0.001; *Chi-square test

Vaginal infections were found in $19.3 \%$ and $4.7 \%$ of cases and controls (OR 4.90, CI 2.07-11.57). Thus, HIV positive status was significantly associated with vaginal infections (Table 6).

Table 6: Distribution of infection according to HIV status.

\begin{tabular}{|llll|}
\hline & HIV positive & HIV negative & Total \\
\hline Infection+ & $29(19.3 \%)$ & $7(4.7 \%)$ & $36(12 \%)$ \\
\hline Infection- & $121(80.7 \%)$ & $143(95.3 \%)$ & $264(88 \%)$ \\
\hline Total & 150 & 150 & 300 \\
\hline
\end{tabular}

\section{DISCUSSION}

Carcinoma cervix remains a major cause of morbidity and mortality among women, especially in developing world, where routine cytological screening is generally unavailable. Squamous intraepithelial lesions (SILs) of the uterine cervix are among the most prevalent gynecological manifestations of HIV infection. In the present study, cytopathological changes and evidences of infection were detected in Pap smear of HIV patients and control were correlated with CD4 counts. All the patients in present study were in reproductive age group (19-45 years). Maximum number of cases $(48.6 \%)$ and controls $(50.6 \%)$ were in the age group of 21-30 years followed by 31-40 years. Mean age in HIV+ve group was 31.2 \pm 6.4 years while in HIV-ve it was $31.7 \pm 6.8$ years which was almost similar to study of Hawes et al in which the mean age was 31.0 years among the cases and 31.9 years among the controls. ${ }^{5}$

Nearly $51 \%$ women had their first intercourse before the age of 18 years in our study. All the women had relation with single partner only while the study by Schuman et al revealed that more than $30 \%$ women had multiple sexual partners. ${ }^{6}$ Discordance can be explained by reluctant behavior of studied patients in disclosing their sexual lives and prevalence of monogamous relationship in our culture.

In the present study, the prevalence of cervical squamous abnormalities among HIV +ve was $12 \%$ (18/150) while among HIV-ve it was $2.7 \%$ (4/150), which has statistically significant difference (OR 18.5, 95\% CI (5.561.7) $\mathrm{p}=0.002)$. In the study of Devi et al prevalence of abnormal Pap smear was $7.17 \%$ in HIV positive women as compare to normal while the study of Micheletti et al observed increase incidence of squamous intraepithelial lesion (SIL) $22.2 \%$ versus $5.9 \%$ in HIV+ve and HIV-ve respectively. ${ }^{7,8}$ In the present study comparative lower incidence of Pap smear abnormalities could be explained because of comparative lesser high risk behavior including intravenous drug abuse, multiple sexual partners and absence of HIV-2 in present study group. In the present study cervical intraepithelial abnormalities increased with progression of disease and increasing immuno-suppression with falling CD4 counts (40\% when CD4 counts $<200$ and $3.5 \%$ when counts $>200$ ) while Six et al observed $7.5 \%$ prevalence for SIL for HIV- ve and $31.3 \%$ for HIV+ve women with CD4 count less than 500 in their study. ${ }^{9}$ In a cross sectional study done at Brazil by Chartuni et al they observed $23 \%$ prevalence of cervical intraepithelial neoplasia in HIV positive women and more with decrease CD4 cell counts (90\% occurrence when count was less than 200). ${ }^{10}$ In present study $46 \%$ women with CD4 count <200cells/ul had vaginal infection while only $11.3 \%$ of those with CD4 count $>200$ cells/ $\mu 1$ had vaginal infections which is statistically significant difference. Almost similar observation was seen in the study of Greenblatt et al $(13 \%, 15 \%, 18 \%$ in women with CD4 counts $>499,200-499$ and 200 cells/ $\mu 1$ respectively). ${ }^{11}$

The prevalence of vaginal infection was $19.3 \%$ in HIV +ve women in present study including Gardenella vaginalis (8\%), Candida albicans (5.3\%), Trichomonas vaginalis $(4 \%)$ and Human papilloma virus $(2 \%)$. While in HIV-ve only $4.7 \%$ had vaginal infections. Similar results were observed in the study of Greenblatt et al, who found that women with HIV infection had candidiasis $15.5 \%$ versus $9 \%$ and bacterial vaginosis $18 \%$ versus $14 \%$ in $\mathrm{HIV}$-ve, but no trichomoniasis whereas Warren et al observed bacterial vaginosis more prevalent in HIV +ve (47\%) as compared to HIV -ve (44\%) in their study. ${ }^{11,12}$

\section{CONCLUSION}

It is concluded that HIV increases the risk of cervical atypia and vaginal infections. Greater frequency was associated with degree of immune-suppression which was detected by CD4 counts. Hence HIV infected women need regular and more frequent gynaecological monitoring and cervical cancer screening.

Funding: No funding sources Conflict of interest: None declared 
Ethical approval: The study was approved by the Institutional Ethics Committee

\section{REFERENCES}

1. Sankaranarayanan R, Budukh AM, Rajkumar R. Effective screening programmes for cervical cancer in low-and middle-income developing countries. Bull World Health Organization. 2001;79:954-62.

2. IARC Working Group on Cervical Cancer Screening. Summary chapter. In: Hakama M, Miller $\mathrm{AB}$, Day NE, editors. Screening for cancer of the uterine cervix. Lyon:IARC Press:1986:133-42(IARC Scientific Publications no76).

3. Lorinz AT, Reid R, Jenson AB, Greenberg MD, Lancaster W, Kurman RJ, et al. Human papillomavirus infection of the cervix: relative risk association of 15 common ano genital types. Obstet Gynecol. 1992;79(3):328-37.

4. Ellerbrock TV, Chiasson MA, Bush TJ, Sun XW, Sawo D, Brudney $\mathrm{K}$ et al. Incidence of cervical squamous intraepithelial lesions in HIV-infected women. JAMA. 2000;283(8):1031-7.

5. Hawes SE, Critchlow CW, Niang MAF, Diop A, Toure P, Dembele B, et al. Increased risk of high grade cervical squamous intraepithelial lesion and invasive cervical cancer among African women with immunodeficiency virus type 1 and 2 infection. J Infectious Dis. 2003;188(4):555-63.

6. Schuman P, Ohmit SE, Klein RS, Duerr A, Cu-Uvin $S$, Jamieson DJ et al. Longitudinal study of cervical squamous intraepithelial lesions in human immunodeficiency virus (HIV)-seropositive and atrisk HIV-seronegative women. $\mathbf{J}$ Infect Dis. 2003;188(1):128-36.
7. Devi KP, Priya NB. Conventional Pap smear screening in HIV seropositive women in South India. J Obstet Gynecol India. 2013;63(1):55-8.

8. Micheletti AM, Dutra VD, Murta EF, Paschoini MC, Silva-Vergara ML, e Silva GB, et al. Cervicovaginal cytological abnormalities in patients with human immunodeficiency virus infection, in relation to disease stage, CD4 cell count and viral load. Diagnostic Cytopathol. 2009;37(3):164-9.

9. Six C, Heard I, Bergeron C, Orth G, Poveda JD, Zagury $\mathrm{P}$, et al. Comparative prevalence, incidence and short-term prognosis of cervical squamous intraepithelial lesions amongst HIV-positive and HIV-negative women. AIDS. 1998;12(9):1047-56.

10. Teixeira NC, Araújo AC, Correa CM, Lodi CT, Lima MI, Carvalho ND, et al. Prevalence and risk factors for cervical intraepithelial neoplasia among HIVinfected women. Brazilian $J$ Infect Dis. 2012;16(2):164-9.

11. Greenblatt RM, Bacchetti P, Barkan S, Augenbraun M, Silver S, Delapenha R, et al. Lower genital tract infections among HIV-infected and high-risk uninfected women: findings of the Women's Interagency HIV Study (WIHS). Sexually Transm Dis. 1999;26(3):143-51.

12. Warren D, Klein RS, Sobel J, Kieke B, Brown W, Schuman P, et al. A multi-centric study of bacterial vaginosis in women with or at risk for human immuno deficiency virus infection. Infect Dis Obstet Gyneol. 2001;9(3):133-41.

Cite this article as: Chauhan $\mathrm{MB}$, Chaudhary $\mathrm{S}$, Singh S, Juneja M, Nanda S. Screening of HIV sero positive women for cervical abnormalities. Int J Reprod Contracept Obstet Gynecol 2018;7:3222-5. 